\title{
Refeeding syndrome in patients with anorexia nervosa - case reports
}

\author{
Zespół realimentacyjny u pacjentek z jadłowstrętem psychicznym - opis przypadków
}

Paweł Stanicki ${ }^{1}$ ABDEF https://orcid.org/0000-0002-4942-9030,

Klaudia Szukała ${ }^{1}$ BDEF, https://orcid.org/0000-0002-8074-133X,

Małgorzata Szypłowska ${ }^{1}$ BDEF, https://orcid.org/0000-0001-9811-8776,

Michał Dzikowski² CE, https://orcid.org/0000-0002-4252-7308

${ }^{1}$ Student Research Group at the I Department of Psychiatry, Psychotherapy and Early Intervention, Medical University of Lublin, Poland

2I Department of Psychiatry, Psychotherapy and Early Intervention, Medical University of Lublin, Poland

\begin{abstract}
Introduction: Refeeding syndrome RS is a life-threatening acute hormonal and metabolic disorder that occurs in patients with moderate or severe malnutrition as a result of improperly administered nutritional therapy.

Material and method: The aim of this study is to describe the cases of two female patients suffering from anorexia nervosa, who developed a refeeding syndrome after starting nutritional therapy. Additionally, the available literature was reviewed in order to characterize the issue, including negative consequences and prevention of the refeeding syndrome.

Results: In both cases, the development of the refeeding syndrome was found in the patients, resulting from the excessive supply of energy and nutritional substrates in a short time, preceded by a previous, months long period of starvation and exhaustion of the organism (both patients had a decrease in the body mass index - BMI - to the value of about $14 \mathrm{~kg} / \mathrm{m}^{2}$ ). In patient 1 , the symptoms concerned mainly the cardiovascular system: a significant increase in the concentration of N-terminal B-type natriuretic propeptide (NT-proBNP) and tachycardia, as well as a decrease in the concentration of inorganic phosphates and hypokalemia. On the other hand, in the case of patient 2, symptoms such as confusion or deep disturbances of consciousness, which led to hospitalization in the intensive care unit, dominated the clinical picture.

Conclusions: Refeeding syndrome may develop during nutritional rehabilitation, especially in the case of a sudden, inadequately planned supply of nutrients. Particular care should be taken in patients with extremely low BMI when reintroducing nutrition. The presented case reports draw attention to the possibility of cardiological complications and mental disorders of the realimentation syndrome, and indicate the behavior of patients (eating excessive food) that may lead to the development of the refeeding syndrome.
\end{abstract}

Keywords: anorexia nervosa, refeeding syndrome, hypophosphataemia, hypokalemia, malnutrition

\section{Streszczenie}

Wstęp: Zespół realimentacyjny to zagrażające życiu ostre zaburzenie hormonalno-metaboliczne, pojawiające się u pacjentów z umiarkowanym lub ciężkim niedożywieniem wskutek nieprawidłowo prowadzonej terapii żywieniowej.

Materiał i metoda: Celem pracy jest opis przypadków dwóch pacjentek chorujących na jadłowstręt psychiczny, u których po rozpoczęciu terapii żywieniowej wystąpił zespół realimentacyjny. Dodatkowo dokonano przeglądu dostępnej literatury celem charakterystyki zagadnienia, w tym negatywnych następstw oraz profilaktyki zespołu realimentacyjnego.

Wyniki: W obu przypadkach stwierdzono u pacjentek rozwój zespołu realimentacyjnego, wynikających ze zbyt dużej podaży substratów energetycznych i odżywczych w krótkim czasie, poprzedzony wcześniejszym, wielomiesięcznym okresem głodzenia i wyniszczenia organizmu (u obu pacjentek obserwowano spadek body mass index - BMI - do wartości około $14 \mathrm{~kg} / \mathrm{m}^{2}$ ). U 1 pacjentki objawy dotyczyły głównie układu sercowo-naczyniowego: znacznego wzrostu stężenia peptydu natriuretycznego typu B (NT-proBNP) oraz tachykardii, a także obniżeniem stężenia fosforanów nieorganicznych oraz hipokaliemii. Natomiast w przypadku pacjentki 2, w obrazie klinicznym dominowały takie objawy takie jak splątanie czy głębokie zaburzenia 
świadomości, które doprowadziły do hospitalizacji w ramach oddziału intensywnej terapii.

Wnioski: Zespół realimentacyjny może rozwinąć się podczas rehabilitacji żywieniowej, zwłaszcza w przypadku nagłej, nieodpowiednio zaplanowanej podaży substancji odżywczych. Należy zachować szczególną ostrożność u pacjentów o skrajnie niskim wskaźniku BMI przy ponownym wprowadzaniu żywienia. Ponadto, należy dokładnie monitorować zachowanie pacjentów z jadłowstrętem psychicznym, biorąc pod uwagę nie tylko możliwość unikania przez nich posiłków lecz również kompulsywnego objadania się. Przedstawione opisy przypadków zwracają uwagę na możliwość wystąpienia powikłań kardiologicznych i zaburzeń psychicznych zespołu realimentacyjnego oraz wskazują zachowania pacjentów (spożywanie nadmiaru jedzenia), które mogą prowadzić do rozwinięcia zespołu ponownego odżywienia.

Słowa kluczowe: jadłowstręt psychiczny, zespół ponownego odżywienia, hipofosfatemia, hipokaliemia, niedożywienie

\section{Introduction}

Anorexia nervosa (AN) is a severe eating disorder in which patient may experience strong fear of weight gain and disturbed body image, resulting in severe dietary restrictions or other behaviors leading to excessive weight loss. It is estimated that in highly developed countries it affects $1 \%$ of women and $<0.5 \%$ of men [1] this percentage depends on the age of the studied group and the diagnostic criteria of AN [2,3]. Anorexia has the highest mortality rate among mental diseases [4]. It is estimated that among patients with anorexia nervosa, $81 \%$ manage to cure or reduce their symptoms, $21 \%$ have chronic eating disorders, and 5\% die [2].

Treatment of AN is based on the implementation of appropriate psychotherapy and supplementing nutritional and energy deficiencies [1]. When treating people with moderate or severe malnutrition, there is a risk of developing refeeding syndrome (RS), also known as food shock syndrome or realimentation syndrome [5,6]. As a result of improperly conducted nutritional therapy (too fast and with too much food), complications may occur, such as: water and electrolyte disturbances (especially hypophosphatemia), vitamin deficiency, metabolic acidosis and even death [6,7]. The aim of the study is to describe the cases of two female patients suffering from anorexia nervosa, who developed refeeding syndrome.

\section{Patient 1}

A 15-year-old patient, she lives with her father and younger sister as well as her father's partner and her two daughters. The patient's mother has been dead for nine years (death due to cancer). Under the care of a psychological clinic for six months, under the care of a psychiatrist for five months. She has a difficult relationship with her stepmother.

The onset of eating disorders about a year earlier, the patient gradually introduced qualitative and quantitative restrictions on the food consumed, resulting in a loss of about $14 \mathrm{~kg}$ (highest body weight $50 \mathrm{~kg}$ with $\mathrm{BMI}=20.00$ $\mathrm{kg} / \mathrm{m}^{2}$, lowest in the summer of the same year). The eating problems were accompanied by deterioration of the mental state in the form of intensified suicidal thoughts and auto-aggressive behavior.

In the eighth month from the onset of eating problems, the patient attempted suicide by ingesting an unknown amount of paracetamol and self-mutilating the skin of her forearms. She was taken to the Emergency Department of the University Children's Hospital (UCH), and then admitted to the Department of Paediatrics, Endocrinology and Diabetology. The girl was admitted three days later, for the first time to the Department of Psychiatry. During the first hospitalization, the patient was found to have a very low body weight - $36 \mathrm{~kg}$ with a height of $158 \mathrm{~cm}$ (BMI $=14.42 \mathrm{~kg} / \mathrm{m}^{2}$ ). Four days after admission, increasing swelling of the lower limbs and rapid weight gain $6 \mathrm{~kg}$ in 4 days), and increasing fatigue were noticed. Tachycardia was also observed, which was absent on admission. Followup examinations were ordered. Compared to the tests on admission, they showed a significant increase in NTproBNP - $704 \mathrm{pg} / \mathrm{ml}$ (previously $62 \mathrm{pg} / \mathrm{ml}$ ), decreasing potassium concentration $-3.65 \mathrm{mmol} / \mathrm{l}$ (previously 4.24 mmol / l), increased concentration of aminotransferase alanine (ALT) - $47.9 \mathrm{U} / \mathrm{l}$ (previously $17.0 \mathrm{U} / \mathrm{l}$ ) and total cholesterol - $260.5 \mathrm{mg} / \mathrm{dl}$ (previously $244.1 \mathrm{mg} / \mathrm{dl}$ ) and a reduced level of inorganic phosphates $-0.5 \mathrm{mmol}$ / l (previously $0.73 \mathrm{mmol} / \mathrm{l}$ ). The tests also showed abnormalities in the red blood cell system: erythrocytes $3.46 \mathrm{M} / \mu \mathrm{l}$, hemoglobin - $10.6 \mathrm{~g} / \mathrm{dl}$, hematocrit $-32.5 \%$. Due to the abnormal NT-proBNP result (at the norm for women up to 16 years of age $<83 \mathrm{pg} / \mathrm{ml}-704 \mathrm{pg} / \mathrm{ml}$ ) and the deteriorating general condition, the girl was referred to the Department of Paediatrics, Endocrinology and Diabetology in order to stabilize the somatic state, where the patient stayed for 9 days. Then she was readmitted to the Department of Psychiatry in order to continue the diagnostic and therapeutic process. At the time of re-admission, the above-mentioned abnormalities in the biochemical tests were not observed, with the exception of the persistently elevated concentration of alanine aminotransferase (ALT) - $47.0 \mathrm{U} / \mathrm{l}$. An electroencephalographic (EEG) examination one week 
after readmission showed no significant abnormalities. After 3 weeks, she was discharged from the ward at the request of her father, against medical recommendations, before completing the therapeutic process. After a few days, she was re-admitted to the ward as an emergency, due to self-mutilation in the left forearm and general deterioration of her mental state, where she stayed until her body weight normalized.

\section{Patient 2}

A 16-year-old patient, a young girl, 3rd grade student, lives with her parents and younger brother (15). The child's development was normal, she was reaching the milestones on time. In kindergarten and school, she did well and achieved high academic results. She had her last period about two years ago.

The onset of eating problems four years ago, when the patient began to restrict her food consumption and undertook excessive physical exercises. She constantly felt fear of weight gain. There was an approximately $10 \mathrm{~kg}$ (19\% of body weight) weight loss. Therefore, the patient was hospitalized for the first time at the Neuropsychiatric Hospital, and then, six months later, at the Department of Psychiatry. In both cases, she was discharged by the family at their own request before the completion of the therapeutic process, against medical recommendations. Two years later, she was admitted to the Department of Endocrinology and Diabetology of the University Children's Hospital in Lublin due to general exhaustion of the organism. During her stay, the patient was aggressive towards other patients and showed a tendency to escape. Then she was transferred to the Department of Psychiatry for further treatment. BMI on admission: 13.3 $\mathrm{kg} / \mathrm{m}^{2}$ (height $167 \mathrm{~cm}$, body weight: $36 \mathrm{~kg}$ ). The results of the patient's laboratory tests showed low levels of total protein $(5.84 \mathrm{~g} / \mathrm{dl}$ at the norm of $6.4-8.3 \mathrm{~g} / \mathrm{dl})$, leukocytes $(3.15 \mathrm{~K} / \mu \mathrm{l}$ at the norm of $4-10 \mathrm{~K} / \mu \mathrm{l})$, significant iron deficiency anemia $(3.0 \mathrm{M} / \mu \mathrm{l}$, hemoglobin 9.6 at the norm of $12-16 \mathrm{~g} / \mathrm{dl}$, hematocrit $27.8 \%$ at the norm of 37-47\%), as well as a high level of ALT (alanine aminotransferase, 63, $1 \mathrm{IU} / \mathrm{l}$ at the norm of 5-34 IU / l). The girl had low blood pressure (on admission 90/62 mm $\mathrm{Hg}$ ). No significant changes were registered in the EEG test. In magnetic resonance imaging of the head, except for the expansion of extracerebral fluid spaces - no changes. Other results with no significant deviations.

During hospitalization, the patient began to eat a significant amount of food, stole sugar from the canteen, as well as other patients' food, while expressing fears that she would "die", "without food she would die". The patient became psychomotorically agitated, disorganized in contact and action, disturbances in consciousness, fresh memory, and sleep disturbances were observed.
The patient required constant supervision. She displayed aggressive behavior towards medical staff and other patients in the ward. It was necessary to use direct coercion in the form of immobilizing the patient. Due to a significant deterioration of the general condition confusion, disturbance of consciousness, uncontrolled physiological needs and the occurrence of symptoms of refeeding syndrome (behavioral disturbances and a reduced level of inorganic phosphates were observed - $0.76 \mathrm{mmol} / \mathrm{l}$ at the norm of $0.84-1.45 \mathrm{mmol} / \mathrm{l}$ ), the girl was transferred to the Intensive Care Unit of UCH in Lublin. After stabilization of the somatic state of the patient, she was re-admitted to the Department of Child and Adolescent Psychiatry, where she stayed until the normalization of her body weight - at discharge she weighed $52.42 \mathrm{~kg}\left(\mathrm{BMI}=18.8 \mathrm{~kg} / \mathrm{m}^{2}\right)$.

\section{Discussion}

It is estimated that approximately $92 \%$ of people suffering from anorexia nervosa are women. There are two types of this disease: restrictive, characterized by limiting food intake to very small amounts, and bulimic type, in which the reduction of food intake is accompanied by periods of overeating or provoking vomiting and overuse of laxatives [8].

As a rule, anorexia coexists with other mental disorders. It is estimated that over $73 \%$ of adolescent women have comorbidities [10].

Refeeding syndrome was first diagnosed during the World War II, when long-term starving prisoners developed heart attacks and peripheral edema after reintroducing nutrition. Currently, it is found in people with anorexia nervosa, chronic malnutrition, patients with kwashiorkor or devastated by neoplastic disease, in whom an attempt is made to resume nutrition too abruptly [12].

There is no clear definition of RS. It is assumed that this is an acute hormonal and metabolic disturbance occurring in debilitated patients who refeed too quickly and / or intensely [6]. The most important marker of this pathology is hypophosphatemia. Apart from it, there are also hypokalemia, hypomagnesaemia, vitamin deficiency (mainly thiamine), hyperglycemia, increased fluid retention (edema) and micronutrient deficiencies [13]. These symptoms are observed when the exhausted organism is obtaining energy from alternative energy sources: amino acids and triglycerides. Suddenly, a violent process of glycolysis begins, requiring an increased supply of phosphate and thiamine. This process is accompanied by the secretion of insulin, which causes the movement of potassium, phosphorus and magnesium ions into the cells, leading to a disturbance of their concentration in blood [6]. Patients with severely lowered BMI are at particular risk of complications related to re-nutrition, including but not 
limited to: arrhythmias, exhaustion, respiratory failure, ataxia, and seizures. An increased risk of developing RS also occurs in the case of unintentional weight loss $>15 \%$ during the last 3-6 months, low or no food intake in the last 10 days, and in people with decreased levels of potassium, phosphorus and magnesium before starting refeeding [14] . In practice, every patient hospitalized for AN is at risk of RS [6]. It was against this background that complications developed in the patients described above.

Unfortunately, currently there is no clear scientific position on the amount of calories a person at risk of RS should consume. It is indicated that electrolyte concentrations should be monitored and special caution should be exercised in the case of severely debilitated patients [6]. It is also important to gradually and slowly increase the caloric supply [15]. The guidelines of the American Society for Parenteral and Enteral Nutrition (ASPEN) suggest (for non-adult patients) starting refeeding at $40 \%-50 \%$ of the target value, usually around 4-6 mg / kg / min of glucose infused with a dose increment of 1-2 mg / kg / min daily [16]. The European guidelines recommend starting refeeding from $5-20 \mathrm{kcal} / \mathrm{kg}$, and the American ones from 30-40 kcal / kg [15]. Recent studies suggest that starting the realimentation of $\mathrm{AN}$ patients with higher energy values $(2000 \mathrm{kcal}$ instead of $1400 \mathrm{kcal}$ ) does not contribute to an increase in the percentage of refeeding syndrome but allows for faster restoration of normal body weight [17].

Additionally, in Patient 1, re-alimentation was accompanied by cardiac complications. A significant increase in NT-proBNP concentration, increased fatigue and tachycardia may indicate heart failure [18]. Previously, cases of cardiogenic shock [19] and cardiac arrest $[20,21]$ in the course of RS in patients with anorexia had been reported. This means that cardiac complications should be taken into account as one of the effects of the refeeding syndrome and special attention should be paid to the careful examination of debilitated patients to avoid cardiological abnormalities.

In the case of Patient 2, the refeeding syndrome also developed as a result of a sudden supply of a high energy diet in a very short time, which led to psychological symptoms such as confusion, lack of control of physiological needs or disturbed consciousness. A similar case, as described above, was presented by Soyam et al. [22], where a patient with AN increased her body weight by more than $13 \mathrm{~kg}$ in 9 days as a result of excessive consumption of food provided by the family, which resulted in the development of the refeeding syndrome. Both of the above cases show the importance of careful monitoring the behavior of patients with anorexia nervosa, not only in terms of avoiding meals, but also binge eating. Additionally, Tenconi et al. indicated that the high intensity of eating disorders symptoms (especially body dissatisfaction) and the early age of the first menstruation are factors that significantly influence the increased risk of compulsive overeating episodes in patients with AN [23].

\section{Conclusions}

Realimentation syndrome is a serious complication of refeeding the debilitated patients. Not only can it cause hormonal and metabolic disorders, but also, as the cases described above show, cardiovascular and mental disorders. The development of a unified definition of this complication will certainly be helpful in the diagnosis of RS. Clinicians should take great care while reintroducing nutrition of debilitated patients in order to better prevent complications of refeeding. It is also necessary to implement the education of physicians in the diagnosis and treatment of the refeeding syndrome.

\section{Wstęp}

Jadłowstręt psychiczny (ang. anorexia nervosa, AN) jest ciężkim zaburzeniem odżywiania, w przebiegu którego można zaobserwować silny lęk przez zwiększeniem masy ciała i zaburzone postrzeganie własnej sylwetki, co skutkuje wprowadzaniem surowych restrykcji w diecie lub innych zachowań prowadzących do nadmiernej utraty masy ciała takimi jak intensywne ćwiczenia fizyczne. Szacuje się, że w krajach wysoko rozwiniętych dotyka ono $1 \%$ kobiet i <0,5\% mężczyzn [1], przy czym odsetek ten zależny jest od wieku badanej grupy oraz od kryteriów diagnostycznych AN [2,3]. Anoreksja odznacza się najwyższą śmiertelnością spośród chorób psychicznych [4]. Szacuje się, że wśród pacjentów z jadłowstrętem psychicznym, 81\% udaje się wyleczyć lub zredukować objawy chorobowe, 21\% ma przewlekłe zaburzenia odżywiania, a 5\% umiera [2].

Leczenie AN opiera się na wdrożeniu odpowiedniej psychoterapii oraz na uzupełnianiu niedoborów odżywczych i energetycznych [1]. W przypadku leczenia osób $\mathrm{z}$ umiarkowanym lub ciężkim niedożywieniem zachodzi ryzyko rozwinięcia się zespołu realimentacyjnego (ang. refeeding syndorme, RS), zwanego również zespołem szoku pokarmowego czy zespołu ponownego żywienia [5,6]. Wskutek nieprawidłowo prowadzonej terapii żywieniowej (zbyt szybko i ze zbyt dużą objętością pokarmu) może dojść do powikłań takich jak: zaburzenia gospodarki wodnoelektrolitowej (w tym szczególnie hipofosfatemia), 
niedobór witamin, kwasica metaboliczna a nawet śmierć $[6,7]$. Celem pracy jest opis przypadków dwóch pacjentek chorujących na jadłowstręt psychiczny, u których rozwinął się zespół realimentacyjny.

\section{Pacjentka 1}

Pacjentka lat 15, mieszka z ojcem i młodszą siostrą oraz partnerką ojca i jej dwoma córkami. Matka pacjentki nie żyje od dziewięciu lat (śmierć $\mathrm{z}$ powodu choroby nowotworowej). Pod opieką poradni psychologicznej od pół roku, pod opieką psychiatry od pięciu miesięcy. Pozostaje w trudnej relacji z macochą.

Początek zaburzeń odżywiania około roku wcześniej, pacjentka stopniowo wprowadzała ograniczenia jakościowe i ilościowe spożywanych pokarmów, skutkujące utratą około $14 \mathrm{~kg}$ (najwyższa masa ciała 50

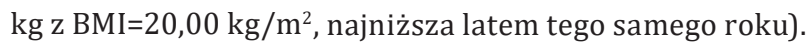
Problemom z odżywianiem towarzyszyło pogorszenie stanu psychicznego pod postacią nasilenia myśli samobójczych i zachowań autoagresywnych.

W ósmym miesiącu od początku problemów z odżywianiem, pacjentka podjęła próbę samobójczą poprzez przyjęcie nieznanej ilości paracetamolu oraz dokonania samookaleczeń skóry przedramion. Została przewieziona na Szpitalny Oddział Ratunkowy Uniwersyteckiego Szpitala Dziecięcego (USzD), a następnie przyjęta na Oddział Pediatrii, Endokrynologii i Diabetologii. Po uzgodnieniu miejsca, dziewczynkę przyjęto po trzech dniach, po raz pierwszy do Kliniki Psychiatrii. Podczas pierwszej hospitalizacji u pacjentki stwierdzono bardzo niską masę ciała - 36 kg przy wzroście $158 \mathrm{~cm}\left(\mathrm{BMI}=14,42 \mathrm{~kg} / \mathrm{m}^{2}\right)$. Cztery dni po rozpoczęciu hospitalizacji zauważono narastające obrzęki kończyn dolnych i szybki przyrost masy ciała (6 kg w 4 dni), oraz narastającą męczliwość. Obserwowano także tachykardię, która była nieobecna przy przyjęciu. Zlecono badania kontrolne. W stosunku do badań przy przyjęciu wykazały one znaczny wzrost NT-proBNP - 704 pg/ml (poprzednio $62 \mathrm{pg} / \mathrm{ml}$ ), obniżające się stężenie potasu - 3,65 mmol/l (poprzednio 4,24 mmol/l), podwyższone stężenie aminotransferazy alaninowej (ALT) - 47,9 U/l (poprzednio 17,0 U/l) i cholesterolu całkowitego - 260,5 $\mathrm{mg} / \mathrm{dl}$ (poprzednio 244,1 mg/dl) oraz obniżony poziom fosforanów nieorganicznych - 0,5 mmol/l (poprzednio $0,73 \mathrm{mmol} / \mathrm{l}$ ). Badania wykazały również odchylenia w zakresie układu czerwonokrwinkowego: krwinki czerwone - 3,46 M/ $\mu \mathrm{l}$, hemoglobina - 10,6 g/dl, hematokryt - 32,5\%. W związku z nieprawidłowym wynikiem NTproBNP (o normach dla kobiet $w$ wieku do 16 lat $<83$ $\mathrm{pg} / \mathrm{ml}$ - $704 \mathrm{pg} / \mathrm{ml}$ ), oraz pogarszającym się stanem ogólnym skierowano dziewczynkę na Oddział Pediatrii, Endokrynologii i Diabetologii celem ustabilizowania stanu somatycznego, gdzie pacjentka przebywała przez
9 dni. Następnie została ponownie przyjęta do Kliniki Psychiatrii celem kontynuowania procesu diagnostycznoleczniczego. W momencie ponownego przyjęcia nie obserwowano już wyżej wymienionych nieprawidłowości w wynikach biochemicznych, z wyjątkiem utrzymującego się podwyższonego stężenie a minotransferazy alaninowej (ALT) - 47,0 U/l. Badanie elektroencefalograficzne (EEG) przeprowadzone tydzień po ponownym przyjęciu nie wykazało znaczących odchyleń od normy. Po 3 tygodniach została wypisana $\mathrm{z}$ oddziału na żądanie ojca wbrew zaleceniom lekarskim przed ukończeniem procesu terapeutycznego. Po kilku dniach ponownie przyjęta do oddziału w trybie nagłym, z powodu dokonanych samouszkodzeń w obrębie lewego przedramienia oraz ogólnego pogorszenia stanu psychicznego, gdzie przebywała do momentu normalizacji masy ciała.

\section{Pacjentka 2}

Pacjentka lat 16, panna, uczennica III klasy gimnazjum, mieszka z rodzicami i młodszym bratem (15 lat). Rozwój dziecka był prawidłowy, kamienie milowe osiągała o czasie. W przedszkolu i szkole radziła sobie dobrze, osiągała wysokie wyniki w nauce. Ostatnią miesiączkę miała ok. 2 lata temu.

Początek problemów odżywianiem przed czterema laty, kiedy to pacjentka zaczęła ograniczać spożywanie pokarmu oraz podejmowała nadmierny wysiłek fizyczny. Stale odczuwała lęk przed wzrostem masy ciała. Nastąpił około $10 \mathrm{~kg}$ (19\% m.c.) spadek masy ciała. W związku z powyższym pacjentka była po raz pierwsza hospitalizowana w Szpitalu Neuropsychiatrycznym, a następnie, pół roku później w Klinice Psychiatrii. W obu przypadkach wypisana przez rodzinę na własne żądanie przed ukończeniem procesu terapeutycznego, wbrew zaleceniom lekarskim. Dwa lata później przyjęta do Oddziału Endokrynologii i Diabetologii Uniwersyteckiego Szpitala Dziecięcego w Lublinie z powodu ogólnego wyniszczenia organizmu. $\mathrm{W}$ trakcie pobytu pacjentka była agresywna wobec innych pacjentów, przejawiała tendencje ucieczkowe. Następnie przeniesiona do Kliniki Psychiatrii celem dalszego leczenia. BMI przy przyjęciu: 13,3 kg/m² (wzrost $167 \mathrm{~cm}$, masa ciała: $36 \mathrm{~kg}$ ). W wynikach badań laboratoryjnych pacjentki można było wyróżnić niskie poziomy białka całkowitego (5,84 g/ dl przy normie 6,4 - 8,3 g/dl), leukocytów (3,15 K/ $\mu$ l przy normie 4 - $10 \mathrm{~K} / \mu \mathrm{l})$, znamienną anemię z niedoboru żelaza (3,0 M/ $\mu \mathrm{l}$, hemoglobina 9,6 przy normie $12-16 \mathrm{~g} / \mathrm{dl}$, hematokryt $27,8 \%$ przy normie $37-47 \%$ ), a także wysoki poziom ALT (aminotransferazy alaninowej, 63,1 IU/l przy normie 5-34 IU/l). Dziewczynka miała niskie ciśnienie (przy przyjęciu 90/62 mm Hg). W badaniu EEG znaczących zmian nie zarejestrowano. W rezonansie magnetycznym głowy, poza poszerzeniem pozamózgowych przestrzeni 
płynowych - bez zmian. Inne wyniki bez znaczących odchyleń.

Pacjentka podczas hospitalizacji zaczęła spożywać znaczne ilości pokarmów, wykradała cukier ze stołówki, a także jedzenie innych pacjentów, jednocześnie wypowiadając obawy, że "umiera", "bez jedzenia umrze". Pacjentka stała się pobudzona psychoruchowo, zdezorganizowana w kontakcie i działaniu, obserwowano zaburzenia świadomości, pamięci świeżej, zaburzenia snu. Pacjentka wymagała stałego nadzoru. Przejawiała zachowania agresywne wobec personelu medycznego oraz innych pacjentów w oddziale. Konieczne było zastosowanie przymusu bezpośredniego w postaci unieruchomienia pacjentki. Ze względu na znaczne pogorszenie stanu ogólnego - splątanie, zaburzenia świadomości, niekontrolowanie potrzeb fizjologicznych oraz wystąpienie objawów zespołu realimentacyjnego (obserwowano zaburzenia zachowania oraz obniżony poziom fosforanów nieorganicznych - 0,76 mmol/l przy normie 0,84-1,45 mmol/l), przeniesiono dziewczynkę na Oddział Intensywnej Opieki Medycznej USzD w Lublinie. Po ustabilizowaniu się stanu somatycznego pacjentki została ponownie przyjęta na tut. Oddział Psychiatrii Dzieci i Młodzieży, gdzie przebywała do momentu normalizacji masy ciała - przy wypisie ważyła 52,42 kg $\left(\mathrm{BMI}=18,8 \mathrm{~kg} / \mathrm{m}^{2}\right)$.

\section{Dyskusja}

Szacuje się, że około $92 \%$ osób chorujących na jadłowstręt psychiczny to kobiety. Wyróżniamy dwa typy tego schorzenia: restrykcyjny charakteryzujący się ograniczaniem przyjmowania pokarmu do bardzo niewielkich ilości oraz typ bulimiczny, w którym zmniejszaniu ilości pokarmu towarzyszą okresy przejadania się lub prowokowania wymiotów i nadużywania leków przeczyszczających [8].

$\mathrm{Z}$ reguły anoreksja współwystępuje $\mathrm{z}$ innymi schorzeniami psychicznymi. Szacuje się, że ponad 73\% dorastających kobiet ma choroby współistniejące [10].

Zespół realimentacyjny po raz pierwszy rozpoznano w czasie II wojny światowej, gdy u więźniów głodujących przez długi czas rozwijały się zawały serca i obrzęki obwodowe wskutek ponownego rozpoczęcia odżywiania. Obecnie jest on stwierdzany u osób $\mathrm{z}$ jadłowstrętem psychicznym, przewlekłym niedożywieniem, chorych na kwashiorkor czy wyniszczonych chorobą nowotworową, u których próbuje się zbyt gwałtowanie wznowić odżywianie [12].

Nie istnieje jednoznaczna definicja RS. Przyjmuje się, iż jest to ostre zaburzenie hormonalno-metaboliczne występujące u pacjentów wyniszczonych, którym zbyt szybko lub/i gwałtowanie włącza się ponowne odżywanie [6]. Najważniejszym markerem tej patologii jest hipofosfatemia. Oprócz niej występują również hipokaliemia, hipomagnezemia, niedobór witamin (głównie tiaminy), hiperglikemia, zwiększona retencja płynów (obrzęki) oraz niedobory mikroelementów [13]. Objawy te są spowodowane pozyskiwaniem energii przez wyniszczony organizm z alternatywnych źródeł energii: aminokwasów i trójglicerydów. Nagle zaczyna się gwałtowny proces glikolizy wymagający zwiększonej podaży reszt fosforanowych i tiaminy. Procesowi temu towarzyszy wydzielanie insuliny, co powoduje przemieszczenie się jonów potasu, fosforu i magnezu do wnętrza komórek, co prowadzi do zaburzeń ich stężenia w surowicy [6]. Pacjenci ze znacznie obniżonym BMI są szczególnie narażeni na powikłania związane z ponownym odżywianiem, do których należą między innymi: zaburzenia rytmu serca, wyczerpanie, niewydolność oddechowa, ataksja czy drgawki. Zwiększone ryzyko rozwoju RS występuje również w przypadku niezamierzonego spadku wagi $>15 \%$ podczas ostatnich 3-6 miesięcy, przyjmowania małych ilości lub nieprzyjmowania pokarmów w ciągu ostatnich $10 \mathrm{dni}$ oraz u osób z obniżonymi poziomami potasu, fosforu i magnezu przed rozpoczęciem realimentacji [14]. W praktyce każdy pacjent hospitalizowany z powodu AN jest w grupie ryzyka RS [6]. Właśnie na takim tle rozwinęły się powikłania u opisywanych powyżej pacjentek.

Pacjentka 1 była hospitalizowana trzykrotnie $\mathrm{z}$ powodu zaburzeń odżywiania i prób samobójczych. Objawy zespołu realimentacyjnego rozwinęły się podczas pierwszego, kilkudniowego pobytu na oddziale w skutek zbyt szybkiego wzrostu masy ciała. W wyniku realimentacji doszło do obniżenia stężenia fosforanów nieorganicznych oraz hipokaliemii.

Niestety nie ma obecnie jednoznacznego stanowiska naukowego co do ilości kalorii, jaką powinna przyjmować osoba zagrożona RS. Wskazuje się na konieczność monitorowania stężeń elektrolitów i zachowania szczególnej ostrożności w przypadku pacjentów znacznie wyniszczonych [6]. Istotnie jest również stopniowe, powolne zwiększanie podaży kalorycznej [15]. Wytyczne American Society for Parenteral and Enteral Nutrition (ASPEN) sugerują (dla pacjentów niedorosłych) rozpoczęcie realimentacji od pułapu 40\%$50 \%$ docelowej wartości, zazwyczaj około 4-6 mg/kg m. c./min glukozy w infuzji ze zwiększaniem dawki o 1-2 $\mathrm{mg} / \mathrm{kg} \mathrm{m}$. c./min codziennie [16]. Wytyczne europejskie zalecają rozpoczęcie realimentacji od 5-20 kcal/kg m.c., amerykańskie zaś od 30-40 kcal/kg [15]. Najnowsze badania sugerują, iż rozpoczęcie realimentacji pacjentów z AN od wyższego pułapu kalorycznego (2000 kcal zamiast 1400 kcal) nie przyczynia się do zwiększenia odsetka występowania zespołu realimentacyjnego a pozwala na szybszą odbudowę prawidłowej masy ciała [17]. 
Dodatkowo u Pacjentki 1 realimentacji współtowarzyszyły powikłania sercowe. Znaczny wzrost stężenia NT-proBNP, nasilona męczliwość oraz tachykardia mogą świadczyć o niewydolności serca [18]. Wcześniej były już opisywane przypadki wstrząsu kardiogennego [19] oraz zatrzymania akcji serca [20,21] w przebiegu RS u pacjentów z anoreksją. Każe to brać pod uwagę powikłania sercowe jako jeden ze skutków zespołu realimentacyjnego oraz zwracać szczególną uwagę na dokładne badanie pacjentów wyniszczonych pod kątem nieprawidłowości kardiologicznych.

W przypadku Pacjentki 2 zespół realimentacyjny także rozwinął się $\mathrm{w}$ wyniku nagłej podaży diety o wysokiej wartości energetycznej w bardzo krótkim odstępie czasu, co doprowadziło do wystąpienia u niej objawów psychicznych takich jak splątanie, niekotrolowanie potrzeb fizjologicznych czy zaburzenia świadomości. Podobny przypadek, jak wyżej opisane został przedstawiony przez Soyama i wsp. [22], gdzie pacjentka z AN zwiększyła masę ciała o ponad 13 kg w ciągu 9 dni wskutek nadmiernego spożywania pokarmów dostarczonych przez rodzinę, co spowodowało rozwinięcie się zespołu realimentacyjnego. Oba powyższe przypadki pokazują zasadność dokładnego monitorowania zachowania pacjentów z jadłowstrętem psychicznym, nie tylko w aspekcie unikania posiłków, lecz również kompulsywnego objadania się. Dodatkowo Tenconi i wsp. wskazali, że wysokie nasilenie objawów zaburzeń odżywiania się (szczególnie niezadowolenie $\mathrm{z}$ własnego ciała), oraz wczesny wiek pierwszej miesiączki są czynnikami mającymi znaczny wpływ na zwiększone ryzyko wystąpienia epizodów kompulsywnego objadania się u osób z AN [23].

\section{Wnioski}

Zespół realimentacyjny jest groźnym powikłaniem ponownego odżywiania pacjentów wyniszczonych. Może powodować nie tylko zaburzenia hormonalnometaboliczne ale również, jak pokazują opisane wyżej przypadki, zaburzenia sercowo-naczyniowe oraz psychiczne. Pomocne $\mathrm{w}$ diagnostyce RS będzie $\mathrm{z}$ pewnością opracowanie ujednoliconej definicji tego powikłania. Klinicyści powinni zachować szczególną ostrożność przy odżywianiu osób wyniszczonych aby lepiej zapobiegać powikłaniom realimentacji. Konieczne jest także wdrożenie edukacji lekarzy w kierunku rozpoznawania oraz leczenia zespołu realimentacyjnego.

\section{Conflict of interest}

The authors have declared no conflict of interest.

\section{References:}

1. Zipfel S, Giel KE, Bulik CM, Hay P, Schmidt U. Anorexia nervosa: aetiology, assessment, and treatment. Lancet Psychiatry. 2015;2(12):1099-111.

2. Roux H, Chapelon E, Godart N. Epidemiology of anorexia nervosa: a review. Encephale. 2013;39(2):85-93.

3. Martínez-González L, Fernández-Villa T, Molina AJ, DelgadoRodríguez M, Martín V. Incidence of Anorexia Nervosa in Women: A Systematic Review and Meta-Analysis. Int J Environ Res Public Health. 2020;17(11):3824.

4. Moskowitz L, Weiselberg E. Anorexia Nervosa/Atypical Anorexia Nervosa. Curr Probl Pediatr Adolesc Health Care. 2017;47(4):70-84.

5. Runde J, Sentongo T. Refeeding Syndrome. Pediatr Ann. 2019;48(11):e448-e454.

6. Skowrońska A, Sójta K, Strzelecki D. Refeeding syndrome as treatment complication of anorexia nervosa. Psychiatr Pol. 2019;53(5):1113-1123.

7. Fuentebella J, Kerner JA. Refeeding syndrome. Pediatr Clin North Am. 2009;56(5):1201-1210.

8. Mitchell JE, Peterson CB. Anorexia Nervosa. N Engl J Med. 2020;382(14):1343-1351.

9. Serra R, Di Nicolantonio C, Di Febo R, De Crescenzo F, Vanderlinden J, Vrieze E, et al. The transition from restrictive anorexia nervosa to binging and purging: a systematic review and meta-analysis. Eat Weight Disord. 2021.

10. Salbach-Andrae $\mathrm{H}$, Lenz $\mathrm{K}$, Simmendinger N, Klinkowski N, Lehmkuhl U, Pfeiffer E. Psychiatric comorbidities among female adolescents with anorexia nervosa. Child Psychiatry Hum Dev. 2008;39(3):261-72.

11. Pompili M, Mancinelli I, Girardi P, Ruberto A, Tatarelli R. Suicide in anorexia nervosa: a meta-analysis. Int J Eat Disord. 2004;36(1):99-103.

12. Tan MCY, Chien JMF, Khor LY, Chea YW, Wong TH. Acute presentation of post-operative kwashiorkor and refeeding syndrome complicated by chronic Strongyloides infection in an elderly patient. ANZ J Surg. 2018 Sep;88(9):E692.

13. Pulcini CD, Zettle S, Srinath A. Refeeding Syndrome. Pediatr Rev. 2016;37:516-523.

14. National Collaborating Centre for Acute Care (UK). Nutrition Support for Adults: Oral Nutrition Support, Enteral Tube Feeding and Parenteral Nutrition. London: National Collaborating Centre for Acute Care (UK); 2006

15. Malczyk Ż, Oświęcimska JM. Gastrointestinal complications and refeeding guidelines in patients with anorexia nervosa. Psychiatr Pol. 2017;51(2):219-229

16. da Silva JSV, Seres DS, Sabino K, Adams SC, Berdahl GJ, Citty SW, et al. ASPEN Consensus Recommendations for Refeeding Syndrome. Nutr Clin Pract. 2020;35(2):178-195.

17. Golden NH, Cheng J, Kapphahn CJ, Buckelew SM, Machen VI, Kreiter A, et al. Refeeding in Anorexia Nervosa: 1-Year Outcomes From a Randomized Controlled Trial. Pediatrics. 2021;147(4):e2020037135.

18. Cao Z, Jia Y, Zhu B. BNP and NT-proBNP as Diagnostic Biomarkers for Cardiac Dysfunction in Both Clinical and Forensic Medicine. Int J Mol Sci. 2019;20(8):1820.

19. Sakamoto Y, Kioka H, Hashimoto R, Takeda S, Momose K, Ohtani $\mathrm{T}$, et al. Cardiogenic shock caused by a left midventricular obstruction during refeeding in a patient with anorexia nervosa. Nutrition. 2017;35:148-150.

20. Kodama M, Kazuma S, Tatsumi H, Goto Y, Aisaka W, Kikuchi K, et al. Cardiac Failure Requiring Veno-Arterial Extracorporeal Membrane Oxygenation (VA-ECMO) Management in a Refeeding Syndrome Patient with Diabetic Ketoacidosis: A Case Report. Am J Case Rep. 2021;22:e930568.

21. Kohn MR, Golden NH, Shenker IR. Cardiac arrest and 
delirium: presentations of the refeeding syndrome in severely malnourished adolescents with anorexia nervosa. J Adolesc Health. 1998;22(3):239-243.

22. Soyama H, Miyamoto M, Natsuyama T, Takano M, Sasa H, Furuya K. A case of refeeding syndrome in pregnancy with anorexia nervosa. Obstet Med. 2018;11(2):95-97.

23. Tenconi E, Lunardi N, Zanetti T, Santonastaso P, Favaro A. Predictors of binge eating in restrictive anorexia nervosa patients in Italy. J Nerv Ment Dis. 2006;194(9):712-715.

\section{Corresponding author}

Paweł Stanicki

Student Research Group at the I Department of Psychiatry, Psychotherapy and Early Intervention, Medical University of Lublin, Poland stanicki99@gmail.com

Otrzymano: 16.11 .2021

Zrecenzowano: 03.01.2022

Przyjęto do druku: 13.01.2022 